\title{
A!
}

This is an electronic reprint of the original article.

This reprint may differ from the original in pagination and typographic detail.

Gurbuz, Ismet Tuna; Lehtonen, Matti; Belahcen, Anouar

\section{Lightning Over-voltages in Nuclear Power Plants}

\section{Published in:}

Proceedings of the 19th International Symposium on Electromagnetic Fields in Mechatronics, Electrical and Electronic Engineering, ISEF 2019

DOI:

10.1109/ISEF45929.2019.9096989

Published: 01/08/2019

Document Version

Publisher's PDF, also known as Version of record

Please cite the original version:

Gurbuz, I. T., Lehtonen, M., \& Belahcen, A. (2019). Lightning Over-voltages in Nuclear Power Plants. In Proceedings of the 19th International Symposium on Electromagnetic Fields in Mechatronics, Electrical and Electronic Engineering, ISEF 2019 [9096989] IEEE. https://doi.org/10.1109/ISEF45929.2019.9096989

This material is protected by copyright and other intellectual property rights, and duplication or sale of all or part of any of the repository collections is not permitted, except that material may be duplicated by you for your research use or educational purposes in electronic or print form. You must obtain permission for any other use. Electronic or print copies may not be offered, whether for sale or otherwise to anyone who is not an authorised user. 
(C) 2019 IEEE. This is the author's version of an article that has been published by IEEE. Personal use of this material is permitted. Permission from IEEE must be obtained for all other uses, in any current or future media, including reprinting/republishing this material for advertising or promotional purposes, creating new collective works, for resale or redistribution to servers or lists, or reuse of any copyrighted component of this work in other works. 


\title{
Lightning Over-voltages in Nuclear Power Plants
}

\author{
İsmet Tuna Gürbüz, Matti Lehtonen, Anouar Belahcen \\ Department of Electrical Engineering and Automation \\ Aalto University \\ Espoo, Finland \\ ismet.gurbuz@aalto.fi, matti.lehtonen@aalto.fi, anouar.belahcen@aalto.fi
}

\begin{abstract}
Lightning has vital effects on power systems. When lightning strikes to the transmission towers, the equipment and the network components are jeopardized by the over-voltages. If the over-voltage magnitudes are more than the basic insulation level (BIL) of the equipment, irreversible damages occur in the system. This paper analyzes lightning over-voltages in two different nuclear power plants (NPP) by applicable modeling and simulations in EMTP-ATPDraw software with different cases of protective device combinations and different scenarios of network structure. In order to keep the over-voltage magnitudes below BILs of the equipment, protection ways are proposed with the surge arresters and the surge capacitances.
\end{abstract}

Index Terms-Basic Insulation Level, Lightning, Nuclear Power Plant, Over-voltage, Surge Arrester, Surge Capacitance

\section{INTRODUCTION}

Lightning is an important meteorological process that threatens both the planet and human being with financial and physical damages. From power systems point of view, when the lightning strikes to a power system, travelling voltage waves having large magnitudes are generated. If the magnitude of the over-voltages exceeds the basic insulation level (BIL) of the equipment, it prevents the proper operation of the equipment and gives damages to the system. Usually, lightning causes the damage in two different ways. The first one is that when the voltage across the equipment increases above a limit, it causes a discharge between the terminals by giving a permanent damage to the electrical insulation of the equipment. The second one is that if the energy of the lightning is higher than the energy handling capacity of the equipment, the equipment may melt or be broken [1]. From the insulation coordination point of view, in order to make the system reliable and secure against these possible effects of lightning, the system has to be analyzed against lightning strokes and protected properly.

There are two types of lightning strokes; direct and indirect stroke. When the lightning strikes to any part of the electrical network, it is defined as direct stroke [1]. Travelling waves are generated as a result of the direct strokes. These travelling waves travel along the line and are often affected by the insulator between the phase conductors and cross-arm of the tower. If the voltage magnitude is high, flash over of the insulator causes short circuit in the system [2]. On the other hand, when the lightning hits to the grounded parts of the system, it might cause an indirect stroke [1]. Travelling waves travel back and forth along the tower and are reflected at the footing and top of the tower, which causes a rise in the voltage and electrical stress on the insulators. Insulator flashes over when the withstand level of the insulator is exceeded. This flash over type is defined as back flashover [2].

In this paper, over-voltages caused by direct lightning stroke in the electric system of two different nuclear power plants (NPP) are analyzed. Electric system of NPPs consists of transmission towers, overhead lines, power transformers, generators, motors, and protective components. These different parts of the systems have been modeled properly for suitable simulations in EMTP-ATPDraw software. After modeling the system parts, direct lightning stroke has been simulated for different cases with the surge arresters and surge capacitance combinations, and different scenarios with different network structures in terms of transmission towers. By using several cases and scenarios, over-voltage magnitude on each phase of each voltage level has been recorded. They have been compared with the BIL of each voltage level, and protection ways have been proposed to keep over-voltage magnitude of the equipment under BIL.

\section{Modeling OF The System}

In this part, the single line diagrams of both NPPs will be shown initially. Then modeling of the system parts will be explained according to single line diagrams.

\section{A. Single Line Diagrams}

Single line diagrams of the first and second NPP are shown in Fig. 1 and Fig. 2 respectively.

The first NPP is composed of four voltage levels as 400 $\mathrm{kV}, 15.75 \mathrm{kV}, 6 \mathrm{kV}$, and $400 \mathrm{~V}$. Between each level, there are power transformers as $415 / 15.75 \mathrm{kV}, 15.75 / 6 \mathrm{kV}$, and $6 / 0.4 \mathrm{kV}$. The generator is in $15.75 \mathrm{kV}$ level and motors are in $6 \mathrm{kV}$ level. The power transformers, the motors, and the generator are protected with the surge arresters. Also, there is a surge capacitance in $15.75 \mathrm{kV}$ level to reduce the overvoltage magnitude.

The second NPP is composed of five voltage levels as 400 $\mathrm{kV}, 20 \mathrm{kV}, 6.9 \mathrm{kV}, 690 \mathrm{~V}$, and $400 \mathrm{~V}$. Between each level, there are power transformers as $415 / 21.5 \mathrm{kV}, 20 / 6.9 \mathrm{kV}, 6.9 / 0.69 \mathrm{kV}$, and $690 / 400 \mathrm{~V}$. The generator is in $20 \mathrm{kV}$ level and motors are in $6.9 \mathrm{kV}$ level. The power transformers, the motors, and the generator are protected with the surge arresters. Also, there is a surge capacitance in $20 \mathrm{kV}$ level to reduce the over-voltage magnitude. 


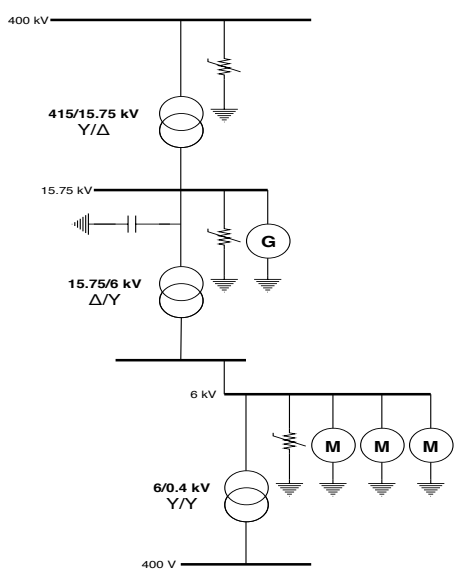

Fig. 1. Single Line Diagram of the First Nuclear Power Plant

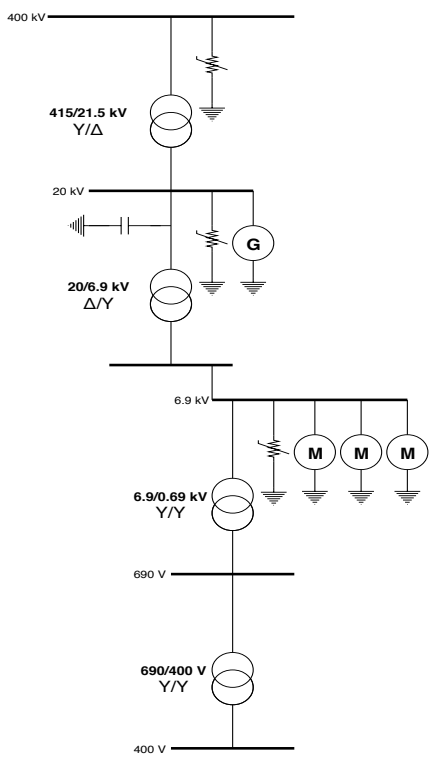

Fig. 2. Single Line Diagram of the Second Nuclear Power Plant

In addition to the parts of the plants in the single line diagrams, four transmission towers, overhead lines, and a lightning source have been modeled for the simulations.

\section{B. Modeling of Lightning Source}

Lightning source has been modeled as a current source, and a $400 \Omega$ parallel resistance has been used for the lightning path [3]. $200 \mathrm{kA}$ and $20 \mathrm{kA}$ magnitudes have been used for the stroke to the ground wire and phase conductors respectively. $1.2 / 50 \mu \mathrm{s}$ front and tail times have been used according to IEC 60060-1 standards [4]. The model can be represented as shown in Fig 3.

\section{Modeling of Transmission Towers}

After the generation of the electricity in the plant, it is stepped-up to the transmission voltage level via a transformer.

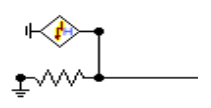

Fig. 3. Lightning Source Model

This voltage is transmitted to the primary and other level transformers via transmission towers and overhead lines. Therefore, in order to investigate the over-voltages in the system, proper implementation of transmission towers and overhead lines is inevitable. For this purpose, $400 \mathrm{kV}$ double circuit configuration has been used for the modeling of transmission towers. The model proposed by [5] has been used as a reference. The proposed model is in Fig. 4.

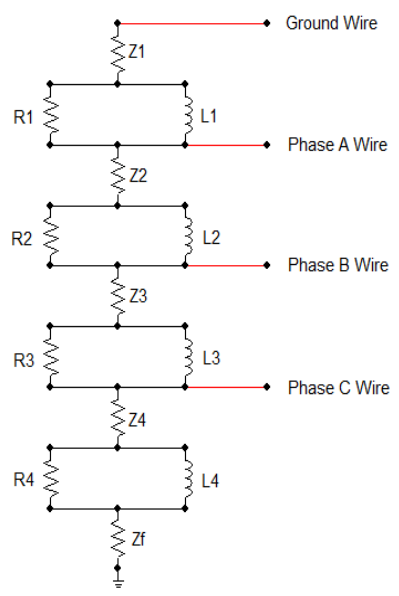

Fig. 4. Transmission Tower Model

By using the dimensions of the selected tower, impedances, reactances, and resistances between the phases have been calculated. To calculate the impedances $\left(Z_{\mathrm{i}}\right)$, cylindrical tower approach has been preferred and they are calculated as in [6] and [7]

$$
Z_{\mathrm{i}}=60 \cdot \ln \left(\sqrt{2} \cdot \frac{2 \cdot h}{r}\right)-60 ; i=1 \ldots 4
$$

where $h$ is the height and $r$ is the radius of the cylindrical tower.

The resistances $\left(R_{\mathrm{i}}\right)$ and inductances $\left(L_{\mathrm{i}}\right)$ have been calculated as in [5]

$$
\begin{gathered}
R_{\mathrm{i}}=\frac{-2 \cdot Z_{\mathrm{i}} \cdot \ln \alpha}{H_{1}+H_{2}+H_{3}} \cdot H_{\mathrm{i}} ; i=1 \ldots 3 \\
R_{4}=-2 \cdot Z_{4} \cdot \ln \alpha \\
H=\sum_{i=1}^{4} H_{i} \\
L_{\mathrm{i}}=\alpha \cdot R_{\mathrm{i}} \frac{2 \cdot H}{C_{0}} ; i=1 \ldots 4
\end{gathered}
$$

where $\alpha$ is the attenuation constant taken as $0.89 . C_{0}$ is the propagation velocity taken as $3 \cdot 10^{8} \mathrm{~m} / \mathrm{s}$, which is the speed 
of the light. $H_{\mathrm{i}}$ are the parameters related to the dimensions of the selected tower.

In addition to the calculated parameters, footing resistance $\left(Z_{\mathrm{f}}\right)$ has been used as $30 \Omega[8]$.

\section{Modeling of Overhead Lines}

Overhead lines have been modeled by $\pi$ equivalent model approach. The parameters of the model have been retrieved from the data of " $400 \mathrm{kV} 2 *$ Finch" overhead line. The length of the overhead lines between two towers has been taken as $250 \mathrm{~m}$.

\section{E. Modeling of Primary Transformers}

In this study, one of the most important part is the modeling of the primary transformers in order to observe the transferred over-voltage to the other levels. Since a power transformer is composed of capacitive and inductive elements, the behavior of the transformer is frequency dependent. Therefore, a model that should work in high frequency is needed. There are two possible methods to find the model parameters of the transformer in high frequencies as (i) using mechanical description and (ii) using frequency response analysis (FRA) data [9]. In this study the second method has been chosen because of the lack of information about the mechanical description and difficulties to calculate the parameters. In order to model $415 / 15.75 \mathrm{kV}$ transformer of the first NPP and 415/21.5 kV transformer of the second NPP, FRA of the transformers have been used. The parameters of the model consisting of inductive and capacitive components have been developed according to FRA of the transformers. The model is represented in Fig. 5.

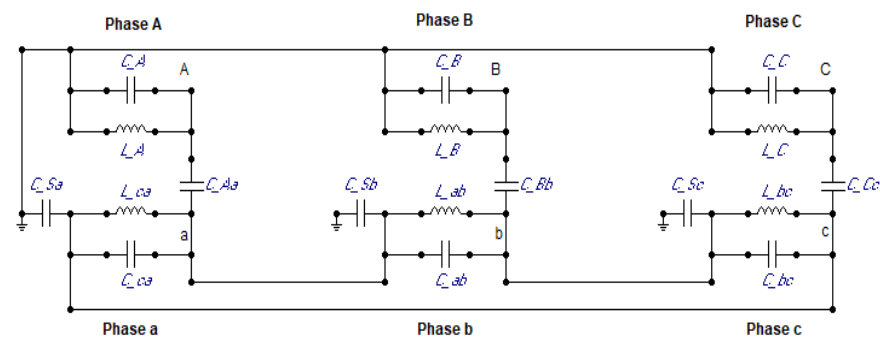

Fig. 5. 415/15.75 kV and 415/21.5 kV Transformer Models in High Frequency

In the model, $C_{\mathrm{A}}, C_{\mathrm{B}}$, and $C_{\mathrm{C}}$ represent the capacitances and $L_{\mathrm{A}}, L_{\mathrm{B}}$, and $L_{\mathrm{C}}$ represent the inductances in the primary sides of each phase. Between the primary and secondary sides of each phase, there are capacitances as $C_{\mathrm{Aa}}, C_{\mathrm{Bb}}$, and $C_{\mathrm{Cc}}$. Between the phases in the secondary side, there are capacitances of $C_{\mathrm{ab}}, C_{\mathrm{bc}}$, and $C_{\mathrm{ca}}$ and inductances of $L_{\mathrm{ab}}, L_{\mathrm{bc}}$, and $L_{\text {ca }}$ similar to primary sides. The inductances and capacitances in the primary and secondary sides are parallel to each other in the model. Moreover, there are additional capacitances in the secondary sides connected to the ground to represent the effect of stray capacitances. These parameters have been calculated according to FRA data of the transformers. FRA of the primary side, FRA of the secondary side, and FRA between primary and secondary sides have been used. The regions in which the transformer shows capacitive or inductive behavior have been determined and capacitances and inductances shown in the model have been found meticulously.

In order to find these values, firstly, end to end test setup has been used for FRA and $50 \Omega$ resistance has been chosen as the measurement impedance. According to these, transfer function is found as

$$
\frac{V_{\text {out }}}{V_{\text {in }}}=\frac{50}{50+Z_{\mathrm{Tr}}}
$$

where $Z_{\mathrm{Tr}}$ is the coil impedance of the transformer. From (6), $Z_{\mathrm{Tr}}$ is expressed as

$$
Z_{\mathrm{Tr}}=50\left(\frac{1-\frac{V_{\text {out }}}{V_{\text {in }}}}{\frac{V_{\text {out }}}{V_{\text {in }}}}\right)
$$

Inductance $(L)$ and capacitance $(C)$ calculations have been made by finding $Z_{\mathrm{Tr}}$ from (7) according to the FRA data and using

$$
\begin{gathered}
L=\frac{x}{\omega} \\
C=\frac{1}{x \cdot \omega}
\end{gathered}
$$

where $x$ is the reactance and $w$ is the angular frequency.

\section{F. Modeling of Secondary and Other Level Transformers}

In order to model $15.75 / 6 \mathrm{kV}$ and $6 / 0.4 \mathrm{kV}$ transformers of the first NPP and 20/6.9 kV, 6.9/0.69 kV, and 690/400 V transformers of the second NPP, the proposed model for the medium voltage distribution systems in [1] has been used. The model can be used for both loaded and unloaded situations. One phase of the model implemented in ATPDraw software is shown in Fig. 6.

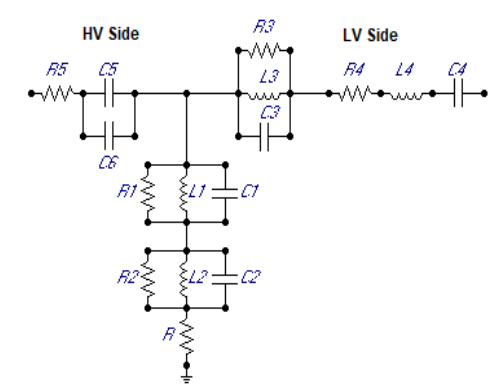

Fig. 6. Secondary and Other Level Transformers' Model

\section{G. Modeling of Surge Arresters}

In this study, surge arresters have one of the most important roles as they are the main protective devices to mitigate the effect of lightning over-voltages. To model surge arresters appropriately, Pinceti's proposed model has been chosen [10]. The model used in ATPDraw is shown in Fig. 7.

The model in Fig. 7 consists of one parallel resistance of $1 \mathrm{M} \Omega$, two inductances as $L_{0}$ and $L_{1}$, and two nonlinear elements as $A_{0}$ and $A_{1}$. According to Pinceti [10], the 


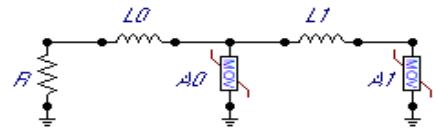

Fig. 7. Surge Arrester Model

parameters of this model are found according to the electrical data of the selected surge arrester. Inductances are found as in (10) and (11).

$$
\begin{aligned}
& L_{0}=0.01 \cdot V_{\mathrm{n}} \\
& L_{1}=0.03 \cdot V_{\mathrm{n}}
\end{aligned}
$$

In (10) and (11), $V_{\mathrm{n}}$ is the rated voltage of the selected surge arrester. For the parameters of $A_{0}$ and $A_{1}, \mathrm{~V}$-I curve characteristics defined by IEEE has been used. The per unit voltage values in the characteristics have been converted to real values and entered to the simulation software.

For the first NPP, surge arresters have been used in $400 \mathrm{kV}$, $15.75 \mathrm{kV}$, and $6 \mathrm{kV}$ levels. For the second NPP, surge arresters have been used in $400 \mathrm{kV}, 20 \mathrm{kV}$, and $6.9 \mathrm{kV}$ levels. Same surge arresters have been preferred for $15.75 \mathrm{kV}$ and $20 \mathrm{kV}$ levels, and $6 \mathrm{kV}$ and $6.9 \mathrm{kV}$ levels. The surge arresters used in [11] for a similar study have been implemented here too. The electrical data of the selected surge arresters can be found in Table I.

TABLE I

ELECTRICAL DATA OF THE SELECTED SURGE ARRESTERS

\begin{tabular}{|c|c|c|c|c|c|}
\hline $\begin{array}{c}\text { Voltage } \\
\text { Level } \\
(\mathbf{k V})\end{array}$ & $\begin{array}{c}\text { Current } \\
\text { Class } \\
(\mathbf{k A})\end{array}$ & $\begin{array}{c}\text { Rated } \\
\text { Voltage } \\
(\mathbf{k V})\end{array}$ & $\begin{array}{c}\text { Max } \\
\mathbf{C O V} \\
(\mathbf{k V})\end{array}$ & $\begin{array}{c}\text { Max RV } \\
\mathbf{8} / \mathbf{2 0} \\
\boldsymbol{\mu s} \mathbf{1 0} \mathbf{~ k A} \\
(\mathbf{k V})\end{array}$ & $\begin{array}{c}\text { Max RV } \\
\mathbf{8} / \mathbf{2 0} \\
\boldsymbol{\mu s} \mathbf{2 0} \text { kA } \\
(\mathbf{k V})\end{array}$ \\
\hline $6,6.9$ & 10 & 8.8 & 7 & 21.5 & 23.8 \\
\hline $15.75,20$ & 10 & 24 & 19 & 58.4 & 73.8 \\
\hline 400 & 20 & 336 & 269 & 808 & 881 \\
\hline
\end{tabular}

\section{Simulations And Results}

After modeling each part of the systems according to single line diagrams, overall models have been simulated in ATPDraw software. Four main studies have been conducted for both NPPs. Direct stroke to the ground wire and phase conductors have been simulated in these studies. For the ground wire case, the impulse having $200 \mathrm{kA}$ magnitude has been applied. On the other hand, for the phase conductors case, $20 \mathrm{kA}$ impulse has been applied. For all studies, 1.2/50 $\mu$ s front and tail times have been used as impulse parameters.

Firstly, the simulations have been made without using a surge capacitance. Then, a surge capacitance of $0.36 \mu \mathrm{F}$ has been used in $15.75 \mathrm{kV}$ level of the first NPP and $20 \mathrm{kV}$ level of the second NPP. The effect of using surge capacitance has been observed with the comparisons.

Four transmission towers exist in the simulation models. Different numbers of transmission towers from 1 to 4 have been simulated with the different stroke locations. Initially, cases without the operation of the surge arresters have been simulated. Then, different combinations with the surge arrester operations have been investigated. Based on the simulation results, proper protection ways for all scenarios have been found to keep over-voltage magnitudes BILs of the equipment. These BILs of the voltage levels of the NPPs can be given in Table II.

TABLE II

BASIC INSULATION LEVELS

\begin{tabular}{|c|c|c|c|c|c|}
\hline \multirow{2}{*}{$\begin{array}{c}\text { Nuclear } \\
\text { Power } \\
\text { Plants }\end{array}$} & \multicolumn{5}{|c|}{ Basic Insulation Levels } \\
\cline { 2 - 6 } & $\begin{array}{c}\mathbf{4 0 0} \boldsymbol{k V} \\
\text { Level }\end{array}$ & $\begin{array}{c}\mathbf{2 0} \boldsymbol{k V} \\
\text { Level }\end{array}$ & $\begin{array}{c}\mathbf{1 5 . 7 5} \boldsymbol{k V} \\
\text { Level }\end{array}$ & $\begin{array}{c}\mathbf{6 . 9} \boldsymbol{k V} \\
\text { Level }\end{array}$ & $\begin{array}{c}\mathbf{6} \boldsymbol{k V} \\
\text { Level }\end{array}$ \\
\hline First NPP & $1640 \mathrm{kV}$ & - & $69 \mathrm{kV}$ & - & $29 \mathrm{kV}$ \\
\hline Second NPP & $1300 \mathrm{kV}$ & $150 \mathrm{kV}$ & - & $29 \mathrm{kV}$ & - \\
\hline
\end{tabular}

Simulation results of the first and second NPP will be given in the following subsections.

\section{A. Simulation Results of the First NPP}

Simulations have been made for various scenarios with different numbers of transmission towers and stroke locations. Different cases with different combinations of surge arrester operations have been investigated. The results for $200 \mathrm{kA}$ $1.2 / 50 \mu \mathrm{s}$ will be given in detail; however, ultimate results with the proposed protection way will be explained in the other studies for simplicity and consistency. Simulation results of Phase A will be given although results have been found for all phases.

1) $200 \mathrm{kA} 1.2 / 50 \mu \mathrm{s}$ Direct Stroke to the Ground Wire: Simulation results for all scenarios and cases without a surge capacitance in $15.75 \mathrm{kV}$ level can be found in Table III. Red colored values show the values above BILs.

In Table III, surge arrester operation in all phases of 400 $\mathrm{kV}, 400 \mathrm{kV}+15.75 \mathrm{kV}$, and $400 \mathrm{kV}+15.75 \mathrm{kV}+6 \mathrm{kV}$ have been investigated. According to the simulation results, operation of the surge arresters in $6 \mathrm{kV}$ level does not have a significant effect in reducing the induced voltage level. Therefore, operation of the surge arresters in $6 \mathrm{kV}$ level is not necessary. However, surge arresters in $15.75 \mathrm{kV}$ level affects the induced voltage level significantly. Without $15.75 \mathrm{kV}$ level surge arresters, BIL in $15.75 \mathrm{kV}$ level is exceeded mostly. Therefore, the system is protected in a best way if $400 \mathrm{kV}$ and $15.75 \mathrm{kV}$ surge arresters are operating although BIL in Phase $\mathrm{A}$ of $400 \mathrm{kV}$ level is exceeded. In order to make that phase below BIL, a surge arrester with different ratings might be preferred.

If a surge capacitance of $0.36 \mu \mathrm{F}$ is used in $15.75 \mathrm{kV}$ level, the results for $400 \mathrm{kV}$ level is almost the same as the results in Table III. However, for $15.75 \mathrm{kV}$ and $6 \mathrm{kV}$ levels, the values decrease almost to the half. In this case, operation of the surge arrestes in $15.75 \mathrm{kV}$ level is unnecessary.

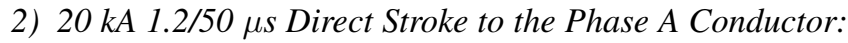
According to the simulations of this case, one surge arrester operation in Phase A of $400 \mathrm{kV}$ level makes the system safe. All phases of each level becomes under BIL. 
TABLE III

Simulation Results FOR $200 \mathrm{KA} 1.2 / 50 \mu$ S DiRECT STROKE TO THE GROUND WIRE IN THE FIRST NPP

\begin{tabular}{|c|c|c|c|c|c|c|}
\hline $\begin{array}{c}\text { Number } \\
\text { of } \\
\text { Towers }\end{array}$ & \begin{tabular}{|c|} 
Tower \\
Number \\
Exposed \\
to Stroke \\
\end{tabular} & Operating Surge Arresters & \begin{tabular}{|c|} 
Induced \\
Voltage Peak \\
on $400 \mathrm{kV}$ \\
Side \\
\end{tabular} & $\begin{array}{c}\text { Induced } \\
\text { Voltage Peak } \\
\text { on } 15.75 \mathrm{kV} \\
\text { Side } \\
\end{array}$ & \begin{tabular}{|c|} 
Induced \\
Voltage \\
Peak on 6 \\
kV Side \\
\end{tabular} & $\begin{array}{c}\text { Induced } \\
\text { Voltage } \\
\text { Peak on } 400 \\
\text { V Side } \\
\end{array}$ \\
\hline & & & Phase A & Phase A & Phase A & Phase A \\
\hline \multirow{4}{*}{1} & \multirow{4}{*}{1} & None & $27 \mathrm{MV}$ & $1.26 \mathrm{MV}$ & $43.3 \mathrm{kV}$ & $17.2 \mathrm{kV}$ \\
\hline & & $400 \mathrm{kV}$ & $1.92 \mathrm{MV}$ & $64.6 \mathrm{kV}$ & $12.6 \mathrm{kV}$ & $9.7 \mathrm{kV}$ \\
\hline & & $400 \mathrm{kV}+15.75 \mathrm{kV}$ & $1.92 \mathrm{MV}$ & $55.2 \mathrm{kV}$ & $12.5 \mathrm{kV}$ & $11.1 \mathrm{kV}$ \\
\hline & & $400 \mathrm{kV}+15.75 \mathrm{kV}+6 \mathrm{kV}$ & $1.92 \mathrm{MV}$ & $55.2 \mathrm{kV}$ & $12.4 \mathrm{kV}$ & $11.1 \mathrm{kV}$ \\
\hline \multirow{8}{*}{2} & \multirow{4}{*}{1} & None & $20 \mathrm{MV}$ & $949.2 \mathrm{kV}$ & $38.8 \mathrm{kV}$ & $14.6 \mathrm{kV}$ \\
\hline & & $400 \mathrm{kV}$ & $1.81 \mathrm{MV}$ & $70.7 \mathrm{kV}$ & $12.5 \mathrm{kV}$ & $10.7 \mathrm{kV}$ \\
\hline & & $400 \mathrm{kV}+15.75 \mathrm{kV}$ & $1.81 \mathrm{MV}$ & $54.9 \mathrm{kV}$ & $12.5 \mathrm{kV}$ & $10.7 \mathrm{kV}$ \\
\hline & & $400 \mathrm{kV}+15.75 \mathrm{kV}+6 \mathrm{kV}$ & $1.81 \mathrm{MV}$ & $54.9 \mathrm{kV}$ & $12.4 \mathrm{kV}$ & $10.7 \mathrm{kV}$ \\
\hline & \multirow{4}{*}{2} & None & $20.3 \mathrm{MV}$ & $952.7 \mathrm{kV}$ & $47 \mathrm{kV}$ & $16.8 \mathrm{kV}$ \\
\hline & & $400 \mathrm{kV}$ & $1.68 \mathrm{MV}$ & $80 \mathrm{kV}$ & $11.5 \mathrm{kV}$ & $4.8 \mathrm{kV}$ \\
\hline & & $400 \mathrm{kV}+15.75 \mathrm{kV}$ & $1.68 \mathrm{MV}$ & $55.9 \mathrm{kV}$ & $8.7 \mathrm{kV}$ & $4.3 \mathrm{kV}$ \\
\hline & & $400 \mathrm{kV}+15.75 \mathrm{kV}+6 \mathrm{kV}$ & $1.68 \mathrm{MV}$ & $55.9 \mathrm{kV}$ & $8.7 \mathrm{kV}$ & $4.3 \mathrm{kV}$ \\
\hline \multirow{12}{*}{3} & \multirow{4}{*}{1} & None & $15.7 \mathrm{MV}$ & $764.3 \mathrm{kV}$ & $38.3 \mathrm{kV}$ & $14.6 \mathrm{kV}$ \\
\hline & & $400 \mathrm{kV}$ & $1.8 \mathrm{MV}$ & $69.2 \mathrm{kV}$ & $12.5 \mathrm{kV}$ & $10 \mathrm{kV}$ \\
\hline & & $400 \mathrm{kV}+15.75 \mathrm{kV}$ & $1.8 \mathrm{MV}$ & $54.7 \mathrm{kV}$ & $12.4 \mathrm{kV}$ & $11.3 \mathrm{kV}$ \\
\hline & & $400 \mathrm{kV}+15.75 \mathrm{kV}+6 \mathrm{kV}$ & $1.8 \mathrm{MV}$ & $54.7 \mathrm{kV}$ & $12.4 \mathrm{kV}$ & $11.3 \mathrm{kV}$ \\
\hline & \multirow{4}{*}{2} & None & $15.5 \mathrm{MV}$ & $726.8 \mathrm{kV}$ & $37.7 \mathrm{kV}$ & $13 \mathrm{kV}$ \\
\hline & & $400 \mathrm{kV}$ & $1.62 \mathrm{MV}$ & $74.5 \mathrm{kV}$ & $11 \mathrm{kV}$ & $4.5 \mathrm{kV}$ \\
\hline & & $400 \mathrm{kV}+15.75 \mathrm{kV}$ & $1.61 \mathrm{MV}$ & $54.7 \mathrm{kV}$ & $8.6 \mathrm{kV}$ & $4.6 \mathrm{kV}$ \\
\hline & & $400 \mathrm{kV}+15.75 \mathrm{kV}+6 \mathrm{kV}$ & $1.61 \mathrm{MV}$ & $54.7 \mathrm{kV}$ & $8.6 \mathrm{kV}$ & $4.6 \mathrm{kV}$ \\
\hline & \multirow{4}{*}{3} & None & $16.6 \mathrm{MV}$ & $770.4 \mathrm{kV}$ & $46.4 \mathrm{kV}$ & $14.7 \mathrm{kV}$ \\
\hline & & $400 \mathrm{kV}$ & $1.57 \mathrm{MV}$ & $79.8 \mathrm{kV}$ & $9.6 \mathrm{kV}$ & $4.3 \mathrm{kV}$ \\
\hline & & $400 \mathrm{kV}+15.75 \mathrm{kV}$ & $1.57 \mathrm{MV}$ & $58.2 \mathrm{kV}$ & $7.6 \mathrm{kV}$ & $4.3 \mathrm{kV}$ \\
\hline & & $400 \mathrm{kV}+15.75 \mathrm{kV}+6 \mathrm{kV}$ & $1.57 \mathrm{MV}$ & $58.2 \mathrm{kV}$ & $7.6 \mathrm{kV}$ & $4.3 \mathrm{kV}$ \\
\hline \multirow{16}{*}{4} & \multirow{4}{*}{1} & None & $13 \mathrm{MV}$ & $637.8 \mathrm{kV}$ & $38.3 \mathrm{kV}$ & $14.6 \mathrm{kV}$ \\
\hline & & $400 \mathrm{kV}$ & $1.8 \mathrm{MV}$ & $63.4 \mathrm{kV}$ & $12.5 \mathrm{kV}$ & $9.8 \mathrm{kV}$ \\
\hline & & $400 \mathrm{kV}+15.75 \mathrm{kV}$ & $1.8 \mathrm{MV}$ & $54.7 \mathrm{kV}$ & $12.4 \mathrm{kV}$ & $11.1 \mathrm{kV}$ \\
\hline & & $400 \mathrm{kV}+15.75 \mathrm{kV}+6 \mathrm{kV}$ & $1.8 \mathrm{MV}$ & $54.7 \mathrm{kV}$ & $12.4 \mathrm{kV}$ & $11.1 \mathrm{kV}$ \\
\hline & \multirow{4}{*}{2} & None & $12.7 \mathrm{MV}$ & $606.6 \mathrm{kV}$ & $36.9 \mathrm{kV}$ & $12.5 \mathrm{kV}$ \\
\hline & & $400 \mathrm{kV}$ & $1.61 \mathrm{MV}$ & $73.7 \mathrm{kV}$ & $10.9 \mathrm{kV}$ & $4.5 \mathrm{kV}$ \\
\hline & & $400 \mathrm{kV}+15.75 \mathrm{kV}$ & $1.61 \mathrm{MV}$ & $54.7 \mathrm{kV}$ & $8.6 \mathrm{kV}$ & $4 \mathrm{kV}$ \\
\hline & & $400 \mathrm{kV}+15.75 \mathrm{kV}+6 \mathrm{kV}$ & $1.61 \mathrm{MV}$ & $54.7 \mathrm{kV}$ & $8.6 \mathrm{kV}$ & $4 \mathrm{kV}$ \\
\hline & \multirow{4}{*}{3} & None & $14.7 \mathrm{MV}$ & $694.5 \mathrm{kV}$ & $34.1 \mathrm{kV}$ & $10.9 \mathrm{kV}$ \\
\hline & & $400 \mathrm{kV}$ & $1.5 \mathrm{MV}$ & $74.1 \mathrm{kV}$ & $9.1 \mathrm{kV}$ & $4.1 \mathrm{kV}$ \\
\hline & & $400 \mathrm{kV}+15.75 \mathrm{kV}$ & $1.5 \mathrm{MV}$ & $56.9 \mathrm{kV}$ & $7.2 \mathrm{kV}$ & $4.1 \mathrm{kV}$ \\
\hline & & $400 \mathrm{kV}+15.75 \mathrm{kV}+6 \mathrm{kV}$ & $1.5 \mathrm{MV}$ & $56.9 \mathrm{kV}$ & $7.2 \mathrm{kV}$ & $4.1 \mathrm{kV}$ \\
\hline & \multirow{4}{*}{4} & & $15.1 \mathrm{MV}$ & $724.3 \mathrm{kV}$ & $42.8 \mathrm{kV}$ & $12.6 \mathrm{kV}$ \\
\hline & & $400 \mathrm{kV}$ & $1.46 \mathrm{MV}$ & $77.1 \mathrm{kV}$ & $8.2 \mathrm{kV}$ & $4.1 \mathrm{kV}$ \\
\hline & & $400 \mathrm{kV}+15.75 \mathrm{kV}$ & $1.46 \mathrm{MV}$ & $58.6 \mathrm{kV}$ & $8.1 \mathrm{kV}$ & $4.1 \mathrm{kV}$ \\
\hline & & $400 \mathrm{kV}+15.75 \mathrm{kV}+6 \mathrm{kV}$ & $1.46 \mathrm{MV}$ & $58.6 \mathrm{kV}$ & $8.1 \mathrm{kV}$ & $4.1 \mathrm{kV}$ \\
\hline
\end{tabular}

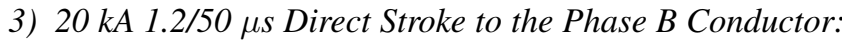
According to the simulations of this case, one surge arrester operation in Phase B of $400 \mathrm{kV}$ level makes the system safe. All phases of each level becomes under BIL.

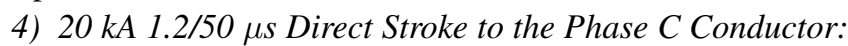
According to the simulations of this case, one surge arrester operation in Phase $\mathrm{C}$ of $400 \mathrm{kV}$ level makes the system safe. All phases of each level becomes under BIL.

\section{B. Simulation Results of the Second NPP}

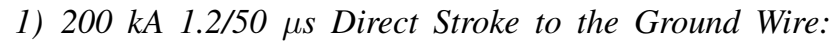
Simulation results for all scenarios and cases without a surge capacitance in $20 \mathrm{kV}$ level can be found in Table IV.

In Table IV, surge arrester operation in all phases of 400 $\mathrm{kV}, 400 \mathrm{kV}+20 \mathrm{kV}$, and $400 \mathrm{kV}+20 \mathrm{kV}+6.9 \mathrm{kV}$ have been investigated. According to the simulation results, similar to the results of the first NPP, operation of the surge arresters in $6.9 \mathrm{kV}$ level does not have a significant effect in reducing the induced voltage level. However, $20 \mathrm{kV}$ level surge arresters reduce the induced voltage level significantly. In contrast with the first NPP, there is no need to operate the surge arresters in $20 \mathrm{kV}$ because voltage level is already below BIL in 20 $\mathrm{kV}$ level without surge arresters due to higher BIL of the
TABLE IV

Simulation RESUlts FOR $200 \mathrm{KA} 1.2 / 50 \mu$ S DiRECT STROKE TO THE GROUND WIRE IN THE SECOND NPP

\begin{tabular}{|c|c|c|c|c|c|c|c|}
\hline $\begin{array}{c}\text { Number } \\
\text { of } \\
\text { Towers }\end{array}$ & \begin{tabular}{|c|} 
Tower \\
Number \\
Exposed \\
to Stroke \\
\end{tabular} & Operating Surge Arresters & \begin{tabular}{|c|} 
Induced \\
Voltage Peak \\
on $400 \mathrm{kV}$ \\
Side \\
\end{tabular} & $\begin{array}{c}\text { Induced } \\
\text { Voltage } \\
\text { Peak on } 20 \\
\text { kV Side }\end{array}$ & $\begin{array}{c}\text { Induced } \\
\text { Voltage } \\
\text { Peak on } 6.9 \\
\text { kV Side } \\
\end{array}$ & $\begin{array}{c}\text { Induced } \\
\text { Voltage } \\
\text { Peak on } 690 \\
\text { V Side } \\
\end{array}$ & $\begin{array}{c}\text { Induced } \\
\text { Voltage } \\
\text { Peak on } 400 \\
\text { V Side }\end{array}$ \\
\hline & & & Phase A & Phase A & Phase A & Phase A & Phase A \\
\hline \multirow{4}{*}{1} & \multirow{4}{*}{1} & None & $25.7 \mathrm{MV}$ & $1.35 \mathrm{MV}$ & $39.8 \mathrm{kV}$ & $5.6 \mathrm{kV}$ & $3.6 \mathrm{kV}$ \\
\hline & & $400 \mathrm{kV}$ & $2 \mathrm{MV}$ & $72.8 \mathrm{kV}$ & $12 \mathrm{kV}$ & $5.5 \mathrm{kV}$ & $3.5 \mathrm{kV}$ \\
\hline & & $400 \mathrm{kV}+20 \mathrm{kV}$ & $2 \mathrm{MV}$ & $58.1 \mathrm{kV}$ & $11.9 \mathrm{kV}$ & $5.5 \mathrm{kV}$ & $3.5 \mathrm{kV}$ \\
\hline & & $400 \mathrm{kV}+20 \mathrm{kV}+6.9 \mathrm{kV}$ & $2 \mathrm{MV}$ & $58.1 \mathrm{kV}$ & $11.9 \mathrm{kV}$ & $5.5 \mathrm{kV}$ & $3.5 \mathrm{kV}$ \\
\hline \multirow{8}{*}{2} & \multirow{4}{*}{1} & None & $19.3 \mathrm{MV}$ & $1.02 \mathrm{MV}$ & $36.3 \mathrm{kV}$ & $5.5 \mathrm{kV}$ & $3.5 \mathrm{kV}$ \\
\hline & & $400 \mathrm{kV}$ & $1.91 \mathrm{MV}$ & $80 \mathrm{kV}$ & $11.9 \mathrm{kV}$ & $5.4 \mathrm{kV}$ & $3.4 \mathrm{kV}$ \\
\hline & & $400 \mathrm{kV}+20 \mathrm{kV}$ & $1.91 \mathrm{MV}$ & $57.5 \mathrm{kV}$ & $11.8 \mathrm{kV}$ & $5.4 \mathrm{kV}$ & $3.4 \mathrm{kV}$ \\
\hline & & $400 \mathrm{kV}+20 \mathrm{kV}+6.9 \mathrm{kV}$ & $1.91 \mathrm{MV}$ & $57.5 \mathrm{kV}$ & $11.8 \mathrm{kV}$ & $5.4 \mathrm{kV}$ & $3.4 \mathrm{kV}$ \\
\hline & \multirow{4}{*}{2} & None & $19.3 \mathrm{MV}$ & $1 \mathrm{MV}$ & $47.5 \mathrm{kV}$ & $4.6 \mathrm{kV}$ & $2.6 \mathrm{kV}$ \\
\hline & & $400 \mathrm{kV}$ & $1.71 \mathrm{MV}$ & $90.8 \mathrm{kV}$ & $12 \mathrm{kV}$ & $1.7 \mathrm{kV}$ & $1.6 \mathrm{kV}$ \\
\hline & & $400 \mathrm{kV}+20 \mathrm{kV}$ & $1.71 \mathrm{MV}$ & $55.4 \mathrm{kV}$ & $8.9 \mathrm{kV}$ & $1.7 \mathrm{kV}$ & $1.6 \mathrm{kV}$ \\
\hline & & $400 \mathrm{kV}+20 \mathrm{kV}+6.9 \mathrm{kV}$ & $1.71 \mathrm{MV}$ & $55.4 \mathrm{kV}$ & $8.9 \mathrm{kV}$ & $1.7 \mathrm{kV}$ & $1.6 \mathrm{kV}$ \\
\hline \multirow{12}{*}{3} & \multirow{4}{*}{1} & None & $15 \mathrm{MV}$ & $804.3 \mathrm{kV}$ & $35.9 \mathrm{kV}$ & $5.5 \mathrm{kV}$ & $3.5 \mathrm{kV}$ \\
\hline & & $400 \mathrm{kV}$ & $1.9 \mathrm{MV}$ & $73.6 \mathrm{kV}$ & $11.9 \mathrm{kV}$ & $5.5 \mathrm{kV}$ & $3.4 \mathrm{kV}$ \\
\hline & & $400 \mathrm{kV}+20 \mathrm{kV}$ & $1.9 \mathrm{MV}$ & $57.3 \mathrm{kV}$ & $11.8 \mathrm{kV}$ & $5.5 \mathrm{kV}$ & $3.4 \mathrm{kV}$ \\
\hline & & $400 \mathrm{kV}+20 \mathrm{kV}+6.9 \mathrm{kV}$ & $1.9 \mathrm{MV}$ & $57.3 \mathrm{kV}$ & $11.8 \mathrm{kV}$ & $5.5 \mathrm{kV}$ & $3.4 \mathrm{kV}$ \\
\hline & \multirow{4}{*}{2} & None & $15.1 \mathrm{MV}$ & $803.4 \mathrm{kV}$ & $35.3 \mathrm{kV}$ & $4.1 \mathrm{kV}$ & $3.5 \mathrm{kV}$ \\
\hline & & $400 \mathrm{kV}$ & $1.57 \mathrm{MV}$ & $84.3 \mathrm{kV}$ & $11.5 \mathrm{kV}$ & $1.6 \mathrm{kV}$ & $1.4 \mathrm{kV}$ \\
\hline & & $400 \mathrm{kV}+20 \mathrm{kV}$ & $1.57 \mathrm{MV}$ & $54.1 \mathrm{kV}$ & $8.8 \mathrm{kV}$ & $1.6 \mathrm{kV}$ & $1.4 \mathrm{kV}$ \\
\hline & & $400 \mathrm{kV}+20 \mathrm{kV}+6.9 \mathrm{kV}$ & $1.57 \mathrm{MV}$ & $54.1 \mathrm{kV}$ & $8.8 \mathrm{kV}$ & $1.6 \mathrm{kV}$ & $1.4 \mathrm{kV}$ \\
\hline & \multirow{4}{*}{3} & None & $15.8 \mathrm{MV}$ & $820.9 \mathrm{kV}$ & $46.7 \mathrm{kV}$ & $4.1 \mathrm{kV}$ & $3.5 \mathrm{kV}$ \\
\hline & & $400 \mathrm{kV}$ & $1.55 \mathrm{MV}$ & $91.5 \mathrm{kV}$ & $11 \mathrm{kV}$ & $1.6 \mathrm{kV}$ & $1.4 \mathrm{kV}$ \\
\hline & & $400 \mathrm{kV}+20 \mathrm{kV}$ & $1.55 \mathrm{MV}$ & $57.5 \mathrm{kV}$ & $6.8 \mathrm{kV}$ & $1.6 \mathrm{kV}$ & $1.4 \mathrm{kV}$ \\
\hline & & $400 \mathrm{kV}+20 \mathrm{kV}+6.9 \mathrm{kV}$ & $1.55 \mathrm{MV}$ & $57.5 \mathrm{kV}$ & $6.8 \mathrm{kV}$ & $1.6 \mathrm{kV}$ & $1.4 \mathrm{kV}$ \\
\hline \multirow{16}{*}{4} & \multirow{4}{*}{1} & None & $12.4 \mathrm{MV}$ & $680.5 \mathrm{kV}$ & $35.9 \mathrm{kV}$ & $5.5 \mathrm{kV}$ & $3.5 \mathrm{kV}$ \\
\hline & & $400 \mathrm{kV}$ & $1.9 \mathrm{MV}$ & $71.4 \mathrm{kV}$ & $11.9 \mathrm{kV}$ & $5.4 \mathrm{kV}$ & $3.4 \mathrm{kV}$ \\
\hline & & $400 \mathrm{kV}+20 \mathrm{kV}$ & $1.9 \mathrm{MV}$ & $57.3 \mathrm{kV}$ & $11.8 \mathrm{kV}$ & $5.4 \mathrm{kV}$ & $3.4 \mathrm{kV}$ \\
\hline & & $400 \mathrm{kV}+20 \mathrm{kV}+6.9 \mathrm{kV}$ & $1.9 \mathrm{MV}$ & $57.3 \mathrm{kV}$ & $11.8 \mathrm{kV}$ & $5.4 \mathrm{kV}$ & $3.4 \mathrm{kV}$ \\
\hline & \multirow{4}{*}{2} & None & $12.3 \mathrm{MV}$ & $659.4 \mathrm{kV}$ & $34.6 \mathrm{kV}$ & $4 \mathrm{kV}$ & $2 \mathrm{kV}$ \\
\hline & & $400 \mathrm{kV}$ & $1.56 \mathrm{MV}$ & $83.3 \mathrm{kV}$ & $11.5 \mathrm{kV}$ & $1.6 \mathrm{kV}$ & $1.2 \mathrm{kV}$ \\
\hline & & $400 \mathrm{kV}+20 \mathrm{kV}$ & $1.56 \mathrm{MV}$ & $54 \mathrm{kV}$ & $8.8 \mathrm{kV}$ & $1.6 \mathrm{kV}$ & $1.2 \mathrm{kV}$ \\
\hline & & $400 \mathrm{kV}+20 \mathrm{kV}+6.9 \mathrm{kV}$ & $1.56 \mathrm{MV}$ & $55 \mathrm{kV}$ & $8.8 \mathrm{kV}$ & $1.6 \mathrm{kV}$ & $1.2 \mathrm{kV}$ \\
\hline & \multirow{4}{*}{3} & None & $14.3 \mathrm{MV}$ & $753.4 \mathrm{kV}$ & $33.1 \mathrm{kV}$ & $3.3 \mathrm{kV}$ & $1.8 \mathrm{kV}$ \\
\hline & & $400 \mathrm{kV}$ & $1.47 \mathrm{MV}$ & $84.9 \mathrm{kV}$ & $11.1 \mathrm{kV}$ & $1.5 \mathrm{kV}$ & $1.2 \mathrm{kV}$ \\
\hline & & $400 \mathrm{kV}+20 \mathrm{kV}$ & $1.47 \mathrm{MV}$ & $56.1 \mathrm{kV}$ & $6.5 \mathrm{kV}$ & $1.5 \mathrm{kV}$ & $1.2 \mathrm{kV}$ \\
\hline & & $400 \mathrm{kV}+20 \mathrm{kV}+6.9 \mathrm{kV}$ & $1.47 \mathrm{MV}$ & $56.1 \mathrm{kV}$ & $6.5 \mathrm{kV}$ & $1.5 \mathrm{kV}$ & $1.2 \mathrm{kV}$ \\
\hline & \multirow{4}{*}{4} & None & $14.4 \mathrm{MV}$ & $761.1 \mathrm{kV}$ & $43 \mathrm{kV}$ & $3.5 \mathrm{kV}$ & $1.3 \mathrm{kV}$ \\
\hline & & $400 \mathrm{kV}$ & $1.48 \mathrm{MV}$ & $88.7 \mathrm{kV}$ & $11.6 \mathrm{kV}$ & $1.5 \mathrm{kV}$ & $1.2 \mathrm{kV}$ \\
\hline & & $400 \mathrm{kV}+20 \mathrm{kV}$ & $1.47 \mathrm{MV}$ & $57.6 \mathrm{kV}$ & $7.6 \mathrm{kV}$ & $1.5 \mathrm{kV}$ & $1.2 \mathrm{kV}$ \\
\hline & & $400 \mathrm{kV}+20 \mathrm{kV}+6.9 \mathrm{kV}$ & $1.47 \mathrm{MV}$ & $57.6 \mathrm{kV}$ & $7.6 \mathrm{kV}$ & $1.5 \mathrm{kV}$ & $1.2 \mathrm{kV}$ \\
\hline
\end{tabular}

equipment $(150 \mathrm{kV})$ than the one in the first NPP $(69 \mathrm{kV})$. Therefore, in order to protect system in a best way, operation of the surge arresters in $400 \mathrm{kV}$ level is sufficient although it doesn't make Phase A of $400 \mathrm{kV}$ level below BIL. A surge arrester with different ratings might be preferred to make that phase below BIL.

If a surge capacitance of $0.36 \mu \mathrm{F}$ is used in $20 \mathrm{kV}$ level, similar to the first NPP, the results for $400 \mathrm{kV}$ level is almost the same as the results in Table IV. However, for $20 \mathrm{kV}$ and $6.9 \mathrm{kV}$ levels, the values decrease almost to the half.

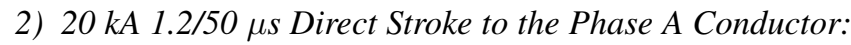
According to the simulations of this case, one surge arrester operation in Phase A of $400 \mathrm{kV}$ level makes the system safe. All phases of each level becomes under BIL.

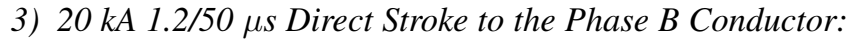
According to the simulations of this case, one surge arrester operation in Phase B of $400 \mathrm{kV}$ level makes the system safe. All phases of each level becomes under BIL.

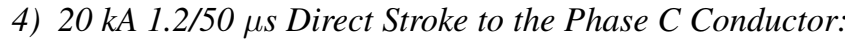
According to the simulations of this case, there is no need to operate any surge arrester as the BILs are not exceeded. 


\section{Summary of the Proposed Protection Ways}

Summary of the proposed protection ways for the first NPP is given in Table $\mathrm{V}$.

TABLE V

Proposed Protection WAYs FOR THE FIRST NPP

\begin{tabular}{|c|c|c|c|c|}
\hline \multicolumn{3}{|c|}{ CASE } & \multicolumn{2}{|c|}{ PROTECTION WAY } \\
\hline $\begin{array}{c}\text { Stroke } \\
\text { Magnitude }\end{array}$ & $\begin{array}{c}\text { Stroke } \\
\text { Location }\end{array}$ & $\begin{array}{l}\text { Surge } \\
\text { Cap. }\end{array}$ & $\begin{array}{c}\text { Surge } \\
\text { Arresters }\end{array}$ & $\begin{array}{c}\text { Operating } \\
\text { Phases }\end{array}$ \\
\hline $200 \mathrm{kA}$ & Ground & $\begin{array}{l}\text { No } \\
\text { Yes }\end{array}$ & $\begin{array}{c}400 \mathrm{kV}+15.75 \mathrm{kV} \\
400 \mathrm{kV}\end{array}$ & All Phases \\
\hline $20 \mathrm{kA}$ & $\begin{array}{l}\text { Phase A } \\
\text { Phase B } \\
\text { Phase C }\end{array}$ & No & $400 \mathrm{kV}$ & $\begin{array}{l}\text { Phase A } \\
\text { Phase B } \\
\text { Phase C }\end{array}$ \\
\hline
\end{tabular}

Summary of the proposed protection ways for the second NPP is given in Table VI.

TABLE VI

Proposed Protection WAYS FOR THE SECOND NPP

\begin{tabular}{|c|c|c|c|c|}
\hline \multicolumn{3}{|c|}{ CASE } & \multicolumn{2}{c|}{ PROTECTION WAY } \\
\hline $\begin{array}{c}\text { Stroke } \\
\text { Magnitude }\end{array}$ & $\begin{array}{c}\text { Stroke } \\
\text { Location }\end{array}$ & $\begin{array}{c}\text { Surge } \\
\text { Cap. }\end{array}$ & $\begin{array}{c}\text { Surge } \\
\text { Arresters }\end{array}$ & $\begin{array}{c}\text { Operating } \\
\text { Phases }\end{array}$ \\
\hline $200 \mathrm{kA}$ & Ground & $\begin{array}{c}\text { No } \\
\text { Yes }\end{array}$ & $400 \mathrm{kV}$ & All Phases \\
\hline \multirow{2}{*}{$20 \mathrm{kA}$} & Phase A & No & $400 \mathrm{kV}$ & $\begin{array}{c}\text { Phase A } \\
400 \mathrm{kV}\end{array}$ \\
& Phase B \\
& Phase C & & - & - \\
\hline
\end{tabular}

\section{Discussions}

In the previous section, the results for the simulations have been investigated and protection ways with the surge arresters have been proposed. In this section, further discussions will be made about the simulation results and proposed protection ways.

According to the results, as the number of the transmission towers increases, the magnitude on each voltage level decreases. As the stroke hits to the towers in the left side, induced voltages on each level increase; however, the magnitude is still less than the scenario with fewer towers. Therefore, in order to protect the system against lightning strokes more, number of transmission towers should be more in the system.

For the first NPP, if $200 \mathrm{kA} 1.2 / 50 \mu$ s direct stroke comes to the ground wire, surge arresters in all phases of $400 \mathrm{kV}$ and $15.75 \mathrm{kV}$ levels should operate. If a surge capacitance of $0.36 \mu \mathrm{F}$ is used in $15.75 \mathrm{kV}$ level, it reduces the voltage magnitude in $15.75 \mathrm{kV}$ level almost to the half and makes the operation of surge arresters in $15.75 \mathrm{kV}$ level unnecessary. If $20 \mathrm{kA} 1.2 / 50 \mu \mathrm{s}$ direct stroke comes to the phase conductors, one surge arrester operation in the corresponding phase of 400 $\mathrm{kV}$ makes the system safe.

For the second NPP, if $200 \mathrm{kA} 1.2 / 50 \mu$ s direct stroke comes to the ground wire, surge arresters in all phases of $400 \mathrm{kV}$ should operate. As BIL of $20 \mathrm{kV}$ level is higher in this case, there is no need to operate the surge arresters in $20 \mathrm{kV}$ level. If a surge capacitance of $0.36 \mu \mathrm{F}$ is used in $20 \mathrm{kV}$ level, it reduces the voltage magnitude almost to the half. If $20 \mathrm{kA}$
$1.2 / 50 \mu$ s direct stroke comes to the Phase A and B conductors, one surge arrester operation in the corresponding phase of 400 $\mathrm{kV}$ level makes the system safe. For Phase $\mathrm{C}$ conductor, there is no need to operate any surge arresters.

For both NPPs, although protection ways have been proposed for $200 \mathrm{kA} 1.2 / 50 \mu$ s direct stroke to the ground wire, the proposed protections are not enough to keep Phase A of $400 \mathrm{kV}$ level under BIL although the other levels are safe. Therefore, a surge arrester with different ratings is needed in $400 \mathrm{kV}$ level.

\section{CONCLUSION}

In this paper, lightning over-voltages in two different NPPs have been investigated. Modeling of the NPPs have been explained and simulation results have been given for different scenarios. Protection ways have been proposed according to simulation results.

This study shows that even if the lightning magnitude is extreme, $200 \mathrm{kA}$, it is possible to protect the system mostly. As an average, lightning magnitude is $20 \mathrm{kA}$ and for that magnitude the system is protected well according to simulation results. Also, this study shows that using a surge capacitance in $15.75 \mathrm{kV}$ and $20 \mathrm{kV}$ levels is beneficial for the protection as it reduces induced voltage values almost to the half.

In order to obtain better results, the primary transformer should be modeled more accurately as it determines the magnitude of the transferred voltage to the other levels. Also, grounding of the transmission towers and the equipment should be studied in more detail because grounding is one of the key factors to determine equivalent impedance of the system parts.

\section{REFERENCES}

[1] N. A. Sabiha, "Lightning-induced overvoltages in medium voltage distribution systems and customer experienced voltage spikes," Ph.D. Dissertation, Aalto University Department of Electrical Engineering and Automation, Finland, 2010.

[2] P. Chowdhuri, "Parameters of lightning strokes and their effects on power systems," in Transmission and Distribution Conference and Exposition, 2001 IEEE/PES, vol. 2, pp. 1047-1051, IEEE, 2001.

[3] A. Ametani and T. Kawamura, "A method of a lightning surge analysis recommended in Japan using EMTP," IEEE Transactions on Power Delivery, vol. 20, no. 2, pp. 867-875, 2005.

[4] IEC, "IEC 60060-1: 2010 High voltage test techniques-part 1: General definitions and test requirements," 2010.

[5] M. Ishii, T. Kawamura, T. Kouno, E. Ohsaki, K. Shiokawa, K. Murotani, and T. Higuchi, "Multistory transmission tower model for lightning surge analysis,' IEEE Transactions on Power Delivery, vol. 6, no. 3, pp. 1327$1335,1991$.

[6] P. C. Á. Mota, J. R. Camacho, and M. L. R. Chaves, "Analysis of tower surge impedance using the finite element method," Electric Power Systems Research, vol. 152, pp. 184-193, 2017.

[7] W. CIGRE, "Guideline for numerical electromagnetic analysis method and its application to surge phenomena," CIGRE Brochure, vol. 543, 2013.

[8] L. Haarla and J. Elovaara, Sähköverkot II. Otaieto Series, 2011.

[9] P. Vaessen, "Transformer model for high frequencies," IEEE Transactions on Power Delivery, vol. 3, no. 4, pp. 1761-1768, 1988.

[10] P. Pinceti and M. Giannettoni, "A simplified model for zinc oxide surge arresters," IEEE Transactions on Power Delivery, vol. 14, no. 2, pp. 393-398, 1999.

[11] D. Subedi, "Lightning induced over-voltages in power transformer and voltage spikes in connected load," M.S. Thesis, Aalto University Department of Electrical Engineering and Automation, Finland, 2017. 